\title{
Prevalence of Depression, Anxiety, and Stress during COVID-19 Pandemic
}

\author{
Ram Lakhan ${ }^{1}$ Amit Agrawal ${ }^{2}$ Manoj Sharma ${ }^{3}$ \\ ${ }^{1}$ Department of Health and Human Performance, Seabury Center, \\ Berea, Kentucky, United States \\ ${ }^{2}$ Department of Neurosurgery, All India Institute of Medical \\ Sciences, Bhopal, Madhya Pradesh, India \\ ${ }^{3}$ Environmental and Occupational Health, School of Public Health, \\ University of Nevada, Las Vegas, Nevada, United States \\ J Neurosci Rural Pract 2020;11:519-525
}

\begin{abstract}
Address for correspondence Ram Lakhan, DrPH, Department of Health and Human Performance, Seabury Center, 101 Chestnut Street, Berea College, CPO 2187, Room No. 229, Berea, Kentucky 40404, United States (e-mail: lakhanr@berea.edu, ramlakhan15@gmail.com).
\end{abstract}

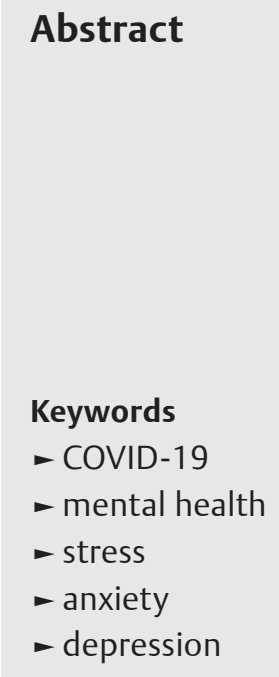

The coronavirus disease 2019 (COVID-19) crisis has greatly affected human lives across the world. Uncertainty and quarantine have been affecting people's mental health. Estimations of mental health problems are needed immediately for the better planning and management of these concerns at a global level. A rapid scoping review was conducted to get the estimation of mental health problems in the COVID-19 pandemic during the first 7 months. Peer-reviewed, data-based journal articles published in the English language were searched in the PubMed, Medline, and Google Scholar electronic databases from December 2019 to June 2020. Papers that met the inclusion criteria were analyzed and discussed in this review. A total of 16 studies were included. Eleven studies were from China, two from India, and one from Spain, Italy, and Iran. Prevalence of all forms of depression was $20 \%$, anxiety $35 \%$, and stress $53 \%$ in the combined study population of 113,285 individuals. The prevalence rate of all forms of depression, anxiety, stress, sleep problems, and psychological distress in general population was found to be higher during COVID-19 pandemic.

\section{Introduction}

The outbreak of the third coronavirus severe acute respiratory syndrome coronavirus 2 (SARS-CoV2), also named coronavirus disease 2019 (COVID-19), has occurred more rapidly than people could have ever imagined from the experience of the past two SARS-CoV and Middle East respiratory syndrome coronavirus. ${ }^{1,2}$ To control the spread of this virus, the entire world acted fast and in collaboration, but the COVID-19 pandemic could not be controlled as it has rather impacted human lives across the globe. In 6 months, in 216 countries including territories, $13,876,441$ people got confirmed for infection and 593,087 lost their lives. ${ }^{3}$ To reduce the risk of COVID-19 exposure, social distancing was suggested and enforced. People of all walks are required to stay in their homes and maintain physical distance in any given situation while they are out for any essential reason., ${ }^{4,5}$ This intervention has not only impacted all ongoing activities but has led to a tremendous negative effect on the mental health of people. The fear of contracting the virus, lack of treatment, higher mortality associated with the virus, and uncertainty about when the virus would be controlled and when a vaccine would be available are the major factors that were found to be highly responsible in increasing psychological distress, adjustment, and even more serious mental health problems. Economic loss, interrupted daily routine, the inability of engaging in social events, and constant news exposure are additional factors that affected mental health. The crisis became an unmanageable stressor. Incidences were even noticed where some people could not handle the mental pressure, and as an escape from traumatizing reality, they committed suicide. ${ }^{6,7}$

Editorials, scientific letters, perspectives, and commentaries in scientific literature and reports in print and visual media have pointed out an increase in mental health problems. Experts across the world expressed concerns for an 
increasing toll of mental health problems and urged for mental health support. ${ }^{8}$ The increase in mental health problems in every society and age group in every nation has turned out to be another important global public health concern during this pandemic. ${ }^{9-16}$ Experts have suggested appropriate and cost-effective ways to address psychological distress and their resulted effects. ${ }^{17} \mathrm{~A}$ lot of attention has been given to this emerging situation with mental health concerns. However, we still lack quantifiable information about the increase in mental health problems due to the pandemic. Policy makers need to know the extent of the problem before making the appropriate arrangements for addressing this issue of increased mental health problems. This scoping review was conducted to provide an estimate of various mental health problems that occurred due to COVID-19.

\section{Objective}

The aim of this study was to review the prevalence of depression, anxiety, stress, and sleep problems during the first 7 months of COVID-19 pandemic.

\section{Methodology}

Articles published in the English language were searched by the first author in the PubMed, Medline, and Google Scholar electronic databases from December 2019 to June 30, 2020. Search with "COVID-19," "coronavirus," "SARS-CoV-2," "nCov," "pandemic," "mental health," "psychiatric problems," "anxiety," "depression," "stress," "psychological distress," and "sleep" words in multiple combinations was performed. Only data-based articles were considered for inclusion. Editorials, perspective, case reports, viewpoints, opinion, letters to the editor, commentaries, secondary data analysis, and review articles were excluded. Gray literature was also excluded. Ahead of print papers were also included. A total of 298 articles, 154 in PubMed/Medline, and 144 in Google Scholar electronic databases containing at least two search words were found. After reading titles, 49 articles that did not meet the title criteria were excluded. Further, 141 articles with duplicate titles were removed and the remaining 108 articles were selected for reading their abstracts. In reading the abstracts or summaries of the articles, 92 articles were excluded for not meeting the inclusion criteria. Remaining 16 articles were read in full and included in the review (-Fig. 1).

\section{Results}

Out of all 16 research studies included in the analysis, 11 studies came from China, two from India, and one each from Italy, Spain, and Iran. Except for one study that followed longitudinal research design, all others followed cross-sectional design. Data on mental health problems for all studies were obtained from 113,285 people in five countries including $87.16 \%$ from China, $9.49 \%$ Iran, $2.44 \%$ Italy, $0.89 \%$ India, and $0.86 \%$ Spain. Eleven studies from China have assessed

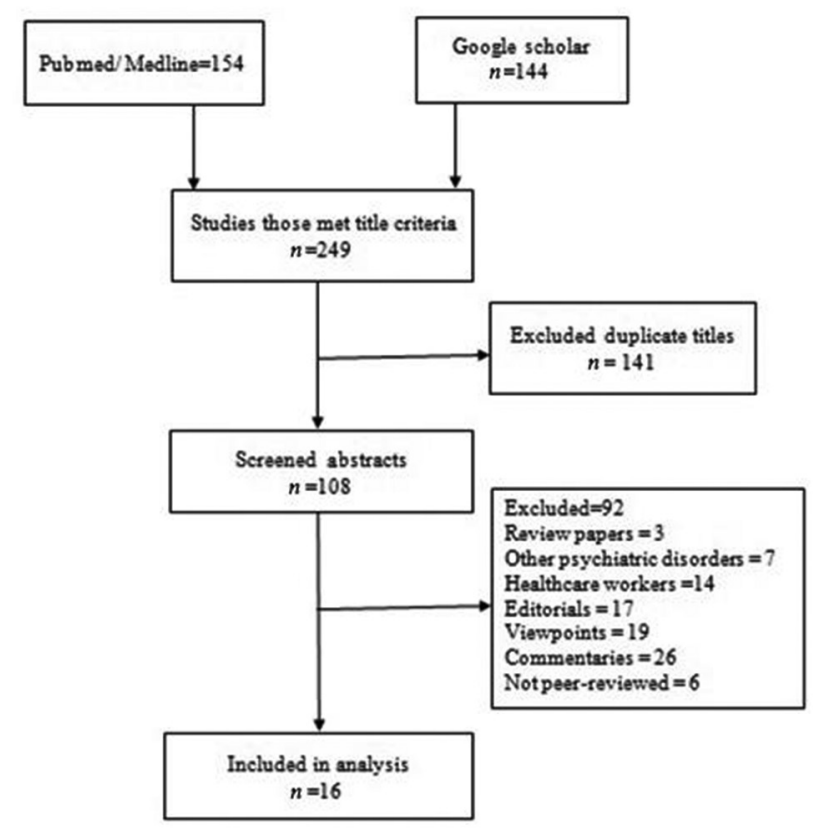

Fig. 1 Flow diagram of the literature search process.

anxiety and out of those, seven assessed both depression and anxiety (-Table 1).

\section{Depression}

The prevalence of depression ranged from 8.3 to $48.3 \%$ in the respondents from China. ${ }^{18-24}$ In India, depression was reported in $25 \%$, Italy 15.4 to $17 \%$, and in Spain $1.7 \%$ extreme depression to $8.7 \%$ mild depression. ${ }^{25-27}$

\section{Anxiety}

The prevalence of anxiety in general population in China ranged from 2 to $37 \%{ }^{18-23,28,25,29,30,31,32}$ In Italy, prevalence of anxiety was found in the range of 7.2 to $11.5 \%,{ }^{26}$ in Spain 1.2 to $4 \%,{ }^{27}$ and in India $\sim 28 \% .{ }^{25,29}$

\section{Stress}

The prevalence of stress in China was found to range between 8.1 and $29.29 \%$ in survey respondents. ${ }^{19-21}$ In India, stress was experienced by $11.6 \%,{ }^{25}$ in Italy by $14.6 \%,{ }^{26}$ and in Spain for men from $0.6 \%$ extreme severe stress to $9.2 \%$ mild stress and for women from $1.2 \%$ extreme severe stress to $8.9 \%$ mild stress. ${ }^{24}$ The prevalence of insomnia ranged from 18.2 to $23.2 \%$ in China $^{18,30}$ (- Table $\mathbf{1}$ ).

\section{Discussion}

Worldwide, researchers have expressed deep concerns toward an increase in mental health issues around the world, in general, as well as, in vulnerable populations. ${ }^{31,32}$ Estimations of the prevalence are needed for the planning 
Table 1 Reviewed studies and their salient findings $(n=16)$

\begin{tabular}{|c|c|c|c|c|c|}
\hline Authors & Country & Study type and scale & $\begin{array}{l}\text { Sample } \\
\text { population }\end{array}$ & $\begin{array}{l}\text { Outcome variable/ } \\
\text { objective }\end{array}$ & Findings \\
\hline $\begin{array}{l}\text { Huang and } \\
\text { Zhao, } 2020^{18}\end{array}$ & China & $\begin{array}{l}\text { Cross-sectional, web- } \\
\text { based. Chinese versions } \\
\text { of generalized anxiety } \\
\text { disorder-7 (GAD-7), The } \\
\text { Center for Epidemiology } \\
\text { Scale for Depression } \\
\text { (CES-D), Pittsburgh } \\
\text { Sleep Quality Index } \\
\text { (PSQI) were used }\end{array}$ & $\begin{array}{l}\text { General public } \\
\text { Sample 7,236 } \\
\text { self-selected } \\
\text { volunteers }\end{array}$ & $\begin{array}{l}\text { To estimate GAD, } \\
\text { depressive symptoms, } \\
\text { and sleep quality }\end{array}$ & $\begin{array}{l}\text { The overall prevalence of GAD was } \\
\text { found } 35.1 \% \text {, depressive symptoms } \\
20.1 \% \text {, and sleep quality } 18.2 \% \\
\text { GAD was found higher among } \\
\text { younger people than older age } \\
\text { people }\end{array}$ \\
\hline $\begin{array}{l}\text { Wang et al, } \\
2020^{19}\end{array}$ & China & $\begin{array}{l}\text { Longitudinal study. } \\
\text { Event Scale-Revised (IES- } \\
\text { R) and the depression, } \\
\text { anxiety and stress scale } \\
\text { (DASS-21) were used }\end{array}$ & $\begin{array}{l}\text { General public } \\
\text { Surveyed twice- } \\
\text { during the initial } \\
\text { outbreak and the } \\
\text { epidemic's peak } \\
4 \text { weeks later } \\
\text { Total sample was } \\
1,738 \text {. First time } \\
1,210 \text { and the sec- } \\
\text { ond time } 861\end{array}$ & $\begin{array}{l}\text { Assessed psycho- } \\
\text { logical impact, } \\
\text { stress, anxiety, and } \\
\text { depression during this } \\
\text { pandemic }\end{array}$ & $\begin{array}{l}\text { In the initial survey, moder- } \\
\text { ate-to-severe stress was found } \\
\text { among } 8.1 \% \text {, anxiety } 28.8 \% \text {, and } \\
\text { depression } 16.5 \% \text {. No significant } \\
\text { changes were noticed in prevalence } \\
\text { in the second round } \\
(p>0.05)\end{array}$ \\
\hline $\begin{array}{l}\text { Qiu et al, } \\
2020^{20}\end{array}$ & China & $\begin{array}{l}\text { Cross-sectional, } \\
\text { nationwide large-scale. } \\
\text { Self-reporting question- } \\
\text { naire was designed-The } \\
\text { COVID-19 Peritraumatic } \\
\text { Distress Index (CPDI). } \\
\text { Cronbach's } \alpha \text { of CPDI is } \\
0.95(p<0.001) \text {. This } \\
\text { tool measured anxiety, } \\
\text { depression, specific } \\
\text { phobias, cognitive } \\
\text { change, avoidance and } \\
\text { compulsive behavior, } \\
\text { physical symptoms, and } \\
\text { loss of social functioning }\end{array}$ & \begin{tabular}{|l|} 
General population. \\
Total of 52,730 \\
people from 36 \\
provinces responded \\
to the survey. Males \\
$18,599(35.27 \%)$ \\
and females 34,131 \\
$(64.73 \%)$
\end{tabular} & $\begin{array}{l}\text { To estimate the prev- } \\
\text { alence of psychologi- } \\
\text { cal distress }\end{array}$ & $\begin{array}{l}\text { A total of } 29.29 \% \text { of respondents } \\
\text { experienced psychological distress. } \\
\text { Females, young adults between } \\
18 \text { to } 30 \text { years and over } 60 \text { years of } \\
\text { age experienced higher psycho- } \\
\text { logical distress compared with } \\
\text { males, younger than } 18 \text { years and } \\
\text { between } 30 \text { and } 60 \text { years of age }\end{array}$ \\
\hline $\begin{array}{l}\text { Wang et al, } \\
2020 .{ }^{21}\end{array}$ & China & $\begin{array}{l}\text { Cross-sectional. An } \\
\text { online survey was con- } \\
\text { ducted using snowball } \\
\text { sampling. } \\
\text { IES-R, and the DASS- } 21 \\
\text { for mental health were } \\
\text { used }\end{array}$ & $\begin{array}{l}\text { General population. } \\
1210 \text { respondents } \\
\text { from } 194 \text { cities } \\
\text { responded to the } \\
\text { survey }\end{array}$ & $\begin{array}{l}\text { To estimate psycho- } \\
\text { logical impact was } \\
\text { assessed }\end{array}$ & $\begin{array}{l}\text { About } 53.8 \% \text { were found to have } \\
\text { some level of stress. Among those, } \\
16.5 \% \text { experienced moder- } \\
\text { ate-to-severe depressive symp- } \\
\text { toms; } 28.8 \% \text { moderate-to-severe } \\
\text { anxiety symptoms; and } 8.1 \% \\
\text { moderate to severe stress }\end{array}$ \\
\hline $\begin{array}{l}\text { Ahmed, et al, } \\
2020^{22}\end{array}$ & China & $\begin{array}{l}\text { Cross-sectional, online } \\
\text { survey. } \\
\text { The Chinese ver- } \\
\text { sion of Beck Anxiety } \\
\text { Inventory (BAI), the Beck } \\
\text { Depression Inventory-II } \\
\text { (BDI-II), the Alcohol Use } \\
\text { Disorder Identification } \\
\text { Test (AUDIT), the } \\
\text { Warwick Edinburgh } \\
\text { Mental Wellbeing Scale } \\
\text { (WEMWBS) were used }\end{array}$ & $\begin{array}{l}\text { 1,074 Chinese } \\
\text { people }\end{array}$ & $\begin{array}{l}\text { To estimate the prev- } \\
\text { alence of depression, } \\
\text { anxiety, hazardous } \\
\text { drinking, and poor } \\
\text { mental well-being } \\
\text { due to lockdown }\end{array}$ & $\begin{array}{l}\text { Approximately } 37.1 \% \text { participants } \\
\text { had different levels of depression } \\
\text { (mild } 10.2 \% \text {, moderate } 17.8 \% \text {, and } \\
\text { severe } 9.1 \% \text { ) } \\
29 \% \text { suffered from different levels } \\
\text { of anxiety (mild } 10.1 \% \text {, moderate } \\
6.0 \% \text { and severe } 12.9 \% \text { ). Hazardous } \\
\text { drinking increased to } 29.1 \% \text {, harm- } \\
\text { ful drinking increased to } 9.5 \% \text {, and } \\
\text { alcohol dependency reached } 1.6 \% \text {. } \\
\text { About } 32.1 \% \text { were found to have } \\
\text { lower mental well-being }\end{array}$ \\
\hline Lei et al, $2020^{28}$ & China & $\begin{array}{l}\text { Cross-sectional study. } \\
\text { Used the } \\
\text { self-rating anxiety scale } \\
\text { (SAS) and the self-rating } \\
\text { depression scale (SDS) }\end{array}$ & $\begin{array}{l}1593 \text { adults aged } \\
18 \text { years and above }\end{array}$ & $\begin{array}{l}\text { To find out the rate of } \\
\text { depression and anxi- } \\
\text { ety between affected } \\
\text { and nonaffected } \\
\text { people }\end{array}$ & $\begin{array}{l}\text { Depression and anxiety were found } \\
\text { to be } 8.3 \% \text { and } 14.6 \% \text { respec- } \\
\text { tively in unaffected people. While } \\
\text { depression and anxiety were found } \\
12.9 \text { and } 22.4 \% \text { of people who had } \\
\text { someone in their family, friends, } \\
\text { relatives, or in the neighborhood } \\
\text { contracting } \\
\text { the virus }\end{array}$ \\
\hline
\end{tabular}


Table 1 (Continued)

\begin{tabular}{|c|c|c|c|c|c|}
\hline Authors & Country & Study type and scale & $\begin{array}{l}\text { Sample } \\
\text { population }\end{array}$ & $\begin{array}{l}\text { Outcome variable/ } \\
\text { objective }\end{array}$ & Findings \\
\hline $\begin{array}{l}\text { Zhou et al, } \\
2020^{23}\end{array}$ & China & $\begin{array}{l}\text { Cross-sectional, online } \\
\text { survey. } \\
\text { Used Patient Health } \\
\text { Questionnaire (PHQ- } \\
\text { 9) and the GAD-7 } \\
\text { questionnaire }\end{array}$ & $\begin{array}{l}\text { Students } 12 \text { to } \\
18 \text { years } \\
\text { Total participants } \\
8079\end{array}$ & $\begin{array}{l}\text { To assess the preva- } \\
\text { lence of depression } \\
\text { and anxiety }\end{array}$ & $\begin{array}{l}\text { The prevalence of depressive } \\
\text { symptoms, anxiety symptoms, } \\
\text { and a combination of depressive } \\
\text { and anxiety symptoms was found } \\
\text { among } 43.7,37.4 \text {, and } 31.3 \% \text {, } \\
\text { respectively }\end{array}$ \\
\hline $\begin{array}{l}\text { Gao et al, } \\
2020^{24}\end{array}$ & China & $\begin{array}{l}\text { Cross-sectional study. } \\
\text { The Chinese version of } \\
\text { WHO-Five Well-Being } \\
\text { Index (WHO-5) and } \\
\text { GAD-7 were used }\end{array}$ & $\begin{array}{l}\text { Chinese citizens } \\
\text { above } 18 \text { years of } \\
\text { age } \\
\text { Total of } 4872 \\
\text { participants }\end{array}$ & $\begin{array}{l}\text { To find out the prev- } \\
\text { alence of depression } \\
\text { and anxiety }\end{array}$ & $\begin{array}{l}\text { The prevalence of depression, anxi- } \\
\text { ety, and combination of depression } \\
\text { and anxiety (CDA) was } 48.3(95 \% \\
\text { confidence interval [Cl]: } 46.9- \\
49.7 \%), 22.6(95 \% \mathrm{Cl}: 21.4-23.8 \%) \text {, } \\
\text { and } 19.4 \% \text { (95\% Cl: } 18.3-20.6 \%), \\
\text { respectively }\end{array}$ \\
\hline $\begin{array}{l}\text { Verma and } \\
\text { Mishra, } 2020^{25}\end{array}$ & India & $\begin{array}{l}\text { Cross-sectional, elec- } \\
\text { tronic survey. } \\
\text { Self-reported DASS- } 21 \\
\text { was used }\end{array}$ & $\begin{array}{l}\text { A total of } 354 \\
\text { respondents com- } \\
\text { pleted survey }\end{array}$ & $\begin{array}{l}\text { To find out the prev- } \\
\text { alence of depression, } \\
\text { anxiety, and stress }\end{array}$ & $\begin{array}{l}\text { In total, } 25 \% \text { had moderate-to-se- } \\
\text { vere depression, } 28 \% \text { anxiety and } \\
11.6 \% \text { stress }\end{array}$ \\
\hline $\begin{array}{l}\text { Mazza et al, } \\
2020^{26}\end{array}$ & Italy & $\begin{array}{l}\text { Cross-sectional, online } \\
\text { survey. The } \\
\text { Italian version of the } \\
\text { DASS-21, and two scales } \\
\text { (negative affect and } \\
\text { detachment) of the } \\
\text { personality inven- } \\
\text { tory, Diagnostic and } \\
\text { Statistical Manual of } \\
\text { Mental Disorders-Fifth } \\
\text { edition (DSM-5-Brief } \\
\text { Form) (Personality } \\
\text { Inventory for DSM- } \\
\text { 5-Brief Form, PID-5-BF) } \\
\text { were used }\end{array}$ & $\begin{array}{l}\text { A total of 2,766 } \\
\text { Italian participants }\end{array}$ & $\begin{array}{l}\text { To find out the prev- } \\
\text { alence of psychiatric } \\
\text { symptoms in the } \\
\text { general population }\end{array}$ & $\begin{array}{l}\text { The prevalence of severe depres- } \\
\text { sion } 15.4 \% \text {, moderate } 17 \% \text {, severe } \\
\text { anxiety } 11.5 \% \text {, and moderate } \\
\text { anxiety } 7.2 \% \text {, and extremely high } \\
\text { stress in } 12.6 \% \text { and high stress in } \\
14.6 \% \text { were found }\end{array}$ \\
\hline $\begin{array}{l}\text { Ozamiz- } \\
\text { Etxebarria et al, } \\
2020^{27}\end{array}$ & Spain & $\begin{array}{l}\text { Cross-sectional. DASS- } \\
21 \text { was used }\end{array}$ & $\begin{array}{l}\text { A total of } 976 \text { adults } \\
\text { took the survey }\end{array}$ & $\begin{array}{l}\text { To estimate the level } \\
\text { of depression, anxi- } \\
\text { ety, and stress in the } \\
\text { general population }\end{array}$ & $\begin{array}{l}\text { Depression in males: mild } 8.7 \text {, } \\
\text { moderate } 4.0 \text {, severe } 2.9 \text {, and } \\
\text { extremely severe } 1.7 \% \text {. In females: } \\
\text { mild } 8.6 \text {, moderate } 7.1 \text {, severe } 2.3 \\
\text { and extremely severe } 3.0 \% \\
\text { Anxiety in male: mild } 4.0 \text {, moder- } \\
\text { ate } 5.2 \text {, severe } 1.2 \text {, and extremely } \\
\text { severe } 3.5 \% \\
\text { In female: mild } 7.0 \text {, moderate } 12.0 \text {, } \\
\text { severe } 3.3 \text {, and extremely severe } \\
3.6 \% \\
\text { Stress in male: mild } 9.2 \text {, moderate } \\
5.2 \text {, severe } 2.9 \text { and extremely } \\
\text { severe } 0.6 \% \text {. In female: mild } 8.9 \text {, } \\
\text { moderate } 9.0 \text {, severe } 3.1 \text {, and } \\
\text { extremely severe } 1.2 \%\end{array}$ \\
\hline $\begin{array}{l}\text { Cao et al, } \\
2020^{38}\end{array}$ & China & $\begin{array}{l}\text { Cross-sectional } \\
\text { GAD-7 }\end{array}$ & $\begin{array}{l}\text { College students } \\
\text { Sample } 7,143 \\
\text { responded }\end{array}$ & $\begin{array}{l}\text { To estimate the prev- } \\
\text { alence of anxiety }\end{array}$ & $\begin{array}{l}\text { Severe anxiety was experienced by } \\
0.9 \text {, moderate anxiety by } 2.7 \text {, and } \\
\text { mild anxiety by } 21.3 \% \text { in college } \\
\text { students. Living in urban, with } \\
\text { parents, and steady income found } \\
\text { to be protective factors against } \\
\text { anxiety }\end{array}$ \\
\hline $\begin{array}{l}\text { Zhang and Ma, } \\
2020^{39}\end{array}$ & China & $\begin{array}{l}\text { Cross-sectional, online } \\
\text { survey. A modified } \\
\text { validated questionnaire } \\
\text { that assessed the IES } \\
\text { was used }\end{array}$ & $\begin{array}{l}\text { Chinese residents } \\
\text { aged } \geq 18 \text { years. } A \\
\text { total of } 263 \text { partic- } \\
\text { ipants, } 106 \text { males, } \\
\text { and } 157 \text { females } \\
\text { responded to the } \\
\text { survey }\end{array}$ & $\begin{array}{l}\text { To assess mental } \\
\text { health and quality } \\
\text { of life }\end{array}$ & $\begin{array}{l}\text { The pandemic situation was } \\
\text { found to be mildly stressful to all. } \\
\text { About } 53.3 \% \text { did not feel helpless, } \\
\text { while } 52.1 \% \text { felt horrified and } \\
\text { apprehensive }\end{array}$ \\
\hline
\end{tabular}


Table 1 (Continued)

\begin{tabular}{|l|l|l|l|l|l|}
\hline Authors & Country & Study type and scale & $\begin{array}{l}\text { Sample } \\
\text { population }\end{array}$ & $\begin{array}{l}\text { Outcome variable/ } \\
\text { objective }\end{array}$ & Findings \\
\hline $\begin{array}{l}\text { Moghanibashi- } \\
\text { Mansourieh, } \\
2020^{40}\end{array}$ & Iran & $\begin{array}{l}\text { Cross-sectional, online } \\
\text { survey. DASS-21 }\end{array}$ & $\begin{array}{l}10,754 \text { individuals } \\
\text { Thou find the associa- }\end{array}$ & $\begin{array}{l}\text { Women had higher rate of anxiety } \\
\text { tion of anxiety rate } \\
\text { with age, gender, } \\
\text { education }\end{array}$ & $\begin{array}{l}\text { did. Compared with other age } \\
\text { groups, people between } 21 \text { and } \\
40 \text { years had the highest rate of } \\
\text { anxiety. Anxiety rate increased with } \\
\text { education }\end{array}$ \\
\hline $2020^{30}$ & China & $\begin{array}{l}\text { Cross-sectional PSQI, } \\
\text { the PHQ-9, and the } \\
\text { GAD-7 were used }\end{array}$ & $\begin{array}{l}\text { Young adults } \\
12-29 \text { years } \\
\text { Participants 11,835 }\end{array}$ & $\begin{array}{l}\text { To find out the preva- } \\
\text { lence of insomnia due } \\
\text { to the pandemic }\end{array}$ & $\begin{array}{l}\text { Prevalence of insomnia was found } \\
\text { 23.2\% }\end{array}$ \\
\hline $\begin{array}{l}\text { Roy, et al, } \\
2020^{29}\end{array}$ & India & $\begin{array}{l}\text { Cross-sectional. An } \\
\text { online survey was } \\
\text { conducted using } \\
\text { a semi-structured } \\
\text { questionnaire using a } \\
\text { nonprobability snowball } \\
\text { sampling technique }\end{array}$ & $\begin{array}{l}\text { General public. } \\
\text { A total of } 662 \\
\text { responses were } \\
\text { received }\end{array}$ & $\begin{array}{l}\text { To assess the } \\
\text { knowledge, attitude, } \\
\text { anxiety experience, } \\
\text { and perceived mental } \\
\text { healthcare need } \\
\text { among the adult } \\
\text { Indian population }\end{array}$ & $\begin{array}{l}\text { The anxiety levels identified in } \\
\text { the study population were found } \\
\text { higher }\end{array}$ \\
\hline
\end{tabular}

purpose. However, the global behaviors and perception in COVID-19 make it difficult to measure true prevalence of emerging rates of mental health problems in the population. ${ }^{33}$ This review is consistent with the call of the researchers that attempted to provide a snapshot of the prevalence rates, which have been estimated around the world. Challenges posed during COVID-19 are much different and wider than the challenges faced by individuals in nonpandemic periods; therefore, it is difficult to compare the finding of this research. However, it is worth emphasizing that the high rate of depression up $20 \%$, anxiety $35 \%$, and stress $53 \%$ in the survey population indicates a high need for preventive and curative care for mental health concerns. Only one study included in this analysis followed a cohort research design that did not demonstrate an increase in the rate of mental health problems during this pandemic. ${ }^{19}$ This information is very crucial. It indicates that some other factors working simultaneously are having protective effects on populations, reducing the escalation of mental health problems. However, the COVID-19 situation has not changed much yet since the beginning. Limited progress has taken place toward the development of a vaccine. The entire world is probably going to live almost in a similar state of uncertainty until a permanent solution to combat this virus is discovered. Looking at the findings of these cross-sectional studies, further increases in mental health problems can be experienced in the future. Unaddressed psychological distress and anxiety experiences for a prolonged period may result in more serious mental health issues. 34,35

\section{Limitations of the Studies}

Some of the major limitations of the included research studies are being cross-sectional, smaller sample sizes, and self-administration of the tests. Research studies have only provided points of prevalence. There is also a high chance of self-reported bias as we know that people can react to news and public perception.

\section{Limitations of This Review}

Because of the urgent nature of the issue, this was a rapid scoping review and as such multiple databases could not be included. Only English Language articles were included and also the gray literature was excluded. As a result, the review cannot claim to be exhaustive of all prevalence studies on the topic that could underestimate or overestimate the prevalence. The review focuses on only the first 7 months and the prevalence rates could be modified as time elapses.

\section{Conclusion}

The findings of this review demonstrate that the occurrence of mental health problems, specifically adjustment and phobia related, has increased in all populations. However, these studies primarily came from developing countries, so there is no scientific estimation of prevalence available of such mental health issues in other countries, specifically in developed nations that have suffered more deaths due to COVID-19. Mental health problems do not always need medical and therapeutic intervention as some of the problems can be healed at community levels. ${ }^{17}$ Does an increase in depression, anxiety, stress, insomnia, and phobia need more medicalized and therapeutic attention during this crisis when mental health experts have the same level of COVID-19-related information, or should mental health experts analyze the situation more carefully, identify protective factors available in the community, and offer more information to the public to adjust in this crisis? This is one of the important questions 
of this review that urges attention for future research. Researchers not only need to find out the pandemic-related global incidence of mental health problems, but they must also evaluate the effect and role of social ecology in the progression and healing of the mental health issue to address this concern more appropriately. ${ }^{17,36,37}$

\section{Conflict of Interest \\ None declared.}

\section{References}

1 NIH. 2020 National Institute for Health. Coronaviruses. Covid19 is an emerging, rapidly evolving situation. Available at: https://www.niaid.nih.gov/diseases-conditions/coronaviruses. Accessed July 17, 2020

2 Sanche S, Lin YT, Xu C, Romero-Severson E, Hengartner N, Ke R. High contagiousness and rapid spread of severe acute respiratory syndrome coronavirus 2. Emerg Infect Dis 2020;26(7):1470-1477

3 WHO. 2020. World Health Orgnisation, Coronavirus disease (COVID-19) pandemic. Available at: https://www.who.int/ emergencies/diseases/novel-coronavirus-2019. Accessed July 18,2020

4 Rundle AG, Park Y, Herbstman JB, Kinsey EW, Wang YC. COVID19-related school closings and risk of weight gain among children. Obesity (Silver Spring) 2020;28(6):1008-1009

5 Sen-Crowe B, McKenney M, Elkbuli A. Social distancing during the COVID-19 pandemic: staying home save lives. Am J Emerg Med 2020;38(7):1519-1520

6 Sahoo S, Rani S, Parveen S, et al. Self-harm and COVID-19 pandemic: An emerging concern - a report of 2 cases from India. Asian J Psychiatr 2020; 51: 102104

7 Mamun MA, Griffiths MD. First COVID-19 suicide case in Bangladesh due to fear of COVID-19 and xenophobia: possible suicide prevention strategies. Asian J Psychiatr 2020;51:10207310.1016/j.ajp.2020.102073

8 Xiang YT, Yang Y, Li W, et al. Timely mental health care for the 2019 novel coronavirus outbreak is urgently needed. Lancet Psychiatry 2020;7(3):228-229

9 Torales J, O'Higgins M, Castaldelli-Maia JM, Ventriglio A. The outbreak of COVID-19 coronavirus and its impact on global mental health. Int J Soc Psychiatry 2020;66(4):317-320

10 Shigemura J, Ursano RJ, Morganstein JC, Kurosawa M, Benedek DM. Public responses to the novel 2019 coronavirus (2019-nCoV) in Japan: mental health consequences and target populations. Psychiatry Clin Neurosci 2020;74(4): 281-282

11 Xie X, Xue Q, Zhou Y, et al. Mental health status among children in home confinement during the coronavirus disease 2019 outbreak in Hubei Province, China. JAMA Pediatr 2020. Doi: $10.1001 /$ jamapediatrics.2020.1619

12 Mukhtar S. Mental health and psychosocial aspects of coronavirus outbreak in Pakistan: psychological intervention for public mental health crisis. Asian J Psychiatr 2020;51:102069. Doi: 10.1016/j.ajp.2020.102069

13 Banerjee D, How COVID-19 is overwhelming our mental health. Nature India; 2020. Doi:10.1038/nindia.2020.46

14 Park SC, Park YC. Mental health care measures in response to the 2019 novel coronavirus outbreak in Korea. Psychiatry Investig 2020;17(2):85-86

15 Zandifar A, Badrfam R. Iranian mental health during the COVID-19 epidemic. Asian J Psychiatr 2020;51:101990

16 Lee J. Mental health effects of school closures during COVID-19. Lancet Child Adolesc Health 2020;4(6):421

17 Pfefferbaum B, North CS. Mental health and the Covid-19 pandemic. N Engl J Med 2020. Doi:10.1056/NEJMp2008017
18 Huang Y, Zhao N. Generalized anxiety disorder, depressive symptoms and sleep quality during COVID-19 outbreak in China: a web-based cross-sectional survey. Psychiatry Res 2020;288:112954

19 Wang C, Pan R, Wan X, et al. A longitudinal study on the mental health of general population during the COVID-19 epidemic in China. Brain Behav Immun 2020;87:40-48

20 Qiu J, Shen B, Zhao M, Wang Z, Xie B, Xu Y. A nationwide survey of psychological distress among Chinese people in the COVID19 epidemic: implications and policy recommendations. Gen Psychiatr 2020;33(2):e100213

21 Wang C, Pan R, Wan X, et al. Immediate psychological responses and associated factors during the initial stage of the 2019 coronavirus disease (COVID-19) epidemic among the general population in China. Int J Environ Res Public Health 2020;17(5):1729

22 Ahmed MZ, Ahmed O, Aibao Z, Hanbin S, Siyu L, Ahmad A. Epidemic of COVID-19 in China and associated Psychological Problems. Asian J Psychiatr 2020;51:102092

23 Zhou SJ, Zhang LG, Wang LL, et al. Prevalence and socio-demographic correlates of psychological health problems in Chinese adolescents during the outbreak of COVID-19. Eur Child Adolesc Psychiatry 2020;29(6):749-758

24 Gao J, Zheng P, Jia Y, et al. Mental health problems and social media exposure during COVID-19 outbreak. PLoS One 2020;15(4):e0231924

25 Verma S, Mishra A. Depression, anxiety, and stress and socio-demographic correlates among general Indian public during COVID-19. Int J Soc Psychiatry 2020;66(8):756-762

26 Mazza C, Ricci E, Biondi S, et al. A nationwide survey of psychological distress among Italian people during the COVID-19 pandemic: Immediate psychological responses and associated factors. Int J Environ Res Public Health 2020;17(9):3165

27 Ozamiz-Etxebarria N, Dosil-Santamaria M, PicazaGorrochategui M, Idoiaga-Mondragon N. Stress, anxiety, and depression levels in the initial stage of the COVID-19 outbreak in a population sample in the northern Spain. Cad Saude Publica 2020;36(4):e00054020

28 Lei L, Huang X, Zhang S, Yang J, Yang L, Xu M. Comparison of prevalence and associated factors of anxiety and depression among people affected by versus people unaffected by quarantine during the COVID-19 epidemic in southwestern China. Med Sci Monit 2020;26:e924609-1-e924609-12

29 Roy D, Tripathy S, Kar SK, Sharma N, Verma SK, Kaushal V. Study of knowledge, attitude, anxiety \& perceived mental healthcare need in Indian population during COVID-19 pandemic. Asian J Psychiatr 2020;51:102083

30 Zhou SJ, Wang LL, Yang R, et al. Sleep problems among Chinese adolescents and young adults during the coronavirus-2019 pandemic. Sleep Med 2020;74: 39-47

31 Holmes EA, O'Connor RC, Perry VH, et al. Multidisciplinary research priorities for the COVID-19 pandemic: a call for action for mental health science. Lancet Psychiatry 2020;7(6): 547-560

32 Pappa S, Ntella V, Giannakas T, Giannakoulis VG, Papoutsi E, Katsaounou P. Prevalence of depression, anxiety, and insomnia among healthcare workers during the COVID-19 pandemic: a systematic review and meta-analysis. Brain Behav Immun. 2020; 88: 901-907

33 Fetzer T, Witte M, Hensel L, et al. Global behaviors and perceptions in the COVID-19 pandemic. Natl Bureau Economic Res; 2020. Doi: $10.31234 /$ osf.io/3kfmh

34 Schneiderman N, Ironson G, Siegel SD. Stress and health: psychological, behavioral, and biological determinants. Annu Rev Clin Psychol 2005;1:607-628

35 Muscatell KA, Slavich GM, Monroe SM, Gotlib IH. Stressful life events, chronic difficulties, and the symptoms of clinical depression. J Nerv Ment Dis 2009;197(3):154-160 
36 Lakhan R, Ekúndayò OT. Application of the ecological framework in depression: an approach whose time has come. AP J Psychol Med 2013;14(2):103-109

37 Bavel JJ, Baicker K, Boggio PS, et al. Using social and behavioural science to support COVID-19 pandemic response. Nat Hum Behav 2020;4(5):460-471

38 Cao W, Fang Z, Hou G, et al. The psychological impact of the COVID-19 epidemic on college students in China. Psychiatry Res 2020;287:112934

39 Zhang Y, Ma ZF. Impact of the COVID-19 pandemic on mental health and quality of life among local residents in Liaoning
Province, China: a cross-sectional study. Int J Environ Res Public Health 2020;17(7):2381

40 Moghanibashi-Mansourieh A. Assessing the anxiety level of Iranian general population during COVID-19 outbreak. Asian J Psychiatr 2020;51:102076 